\title{
「学 問」
}

2019 年度通信ソサイエティ会長 大槻知明

Tomoaki Ohtsuki

日，産業界を含めた様々な分野で，ビッグデータや

人工知能 $(\mathrm{Al})$ が話題になっています．人工知能を 用いてビッグデータを分析することで, 多種多様なデータ 間の関係を見つけ出し，より最適に近い解を提供できるよ うになりました. そして, 多くの応用例で, 人間を凌駕す る性能を示しています. アルファ碁が, 世界トップレベル のプロ棋士に勝利したことは, 記憶に新しいと思います. 週刊誌では,「人工知能で消える職業一覧」という特集が組 まれています. 2013 年に出版された英国オックスフォード 大学の A. Osborne 准教授らの論文, “The future of employ ment: How susceptible are jobs to computerisation?” では, 今後 10 20 年程度で, 米国の総雇用者の約 47\% の仕事が 自動化されるリスクが高いと報告されています.

人工知能が近年再び注目されるようになったのには, 様々 な要因があります．その大きな要因として, ビッグデータ の収集が可能になったこと, それを処理する深層学習など のアルゴリズムが進展したこと, アルゴリズムの実装に適 した GPU (Graphics Processing Unit) が高速かつ安価に なったこと, などの技術的発展が挙げられます．言うまで もなく, これら技術発展には, 電子情報通信学会も大きく 貢献しています.

今日, 産業界では, 人工知能を活用するための知識や, それを扱える人材が求められています。しかし，ビッグデ 一タや人工知能の急速な発展 - 普及に伴って, 以前に比べ, 産業界と電子情報通信学会の結び付きが強くなったという 話は，残念ながら聞きません，それどころか，電子情報通 信学会では, 長きにわたって企業会員数の減少が問題にな っています.

また, 電子情報通信学会は, 2017 年に創立 100 周年を 迎えましたが, その際, 企業の皆様から本会に対して多く の指摘・注文がありました. 詳しくは, 1 年前の本マガジ ンに掲載された漆谷平成 30 年度通信ソサイエティ会長の巻 末言を御覧頂きたいのですが, 頂いた御指摘の要点は, 現 在の電子情報通信学会は大学の研究と論文が中心となって おり, 多くの企業が期待する内容（技術トレンドや戦略の 把握）とは程遠く, 競合あるいは異業種の企業との出会い
の場になっておらず, 将来の大きな流れも示していないと いう, 厳しいものでした. 必ずしも全てが御指摘とおりで はないと思いますが，このような御意見を持たれている企 業の方々が複数いるという事実は重要です. 我々の情報発 信に足らない点があることも, 原因の一つと考えられます. また, 御指摘にあるように改善すべき点も多々あると思い ます.

例えば, 人工知能分野は, 情報学だけでなく, 脳科学, 物性科学, 電子工学ほか, 様々な学問分野にまたがっており, 学際的な取組みが重要です。また, 技術分野からでなく, エネルギー・水・環境・食料・持続可能性社会・社会基盤 安全などの社会問題から見ても, 特定分野のエンジニア（エ 学者) だけでなく, 経済学, 社会学, 法学, 公共政策学, 人文科学等, 様々な分野の研究者の協力した取組みが必要 です.

このように, 大きな社会変革が起こり, 社会問題も複雑 かつ学際的な取組みが必要になっている今日, 電子情報通 信学会も学際的な取組みを増やしていく必要があると考え ます.

慶應義塾の創始者である福澤諭吉は, 「学問のす >め」の 中で, 「学問の道に於て, 談話, 演説の大切なるは既に明白 にして，今日これを実に行ふ者なきは何ぞや」と述べてい ます，福澤は，「実学」に「サイヤンス」と振り仮名を振り ました. 福澤の言う「学問」とは,「学習」とは区別され, また単なる実用の学ではない「実学（サイヤンス）」, すな わち,「科学」であり,でき上がった知識を単に学ぶことで はなく, 問題を発見し, 仮説を立てて検証し, 結論を導い ていくという, 新しい知識の創造を指しています. そして, 「学問」には「談話」や「演説」が重要であると述べています. 更に福澤は, Society を「人間交際（じんかんこうさい）」 と訳しており，「学問」とは「人間交際」の発展に伴うべき であるという確信があったと思われます.

電子情報通信学会が,「談話」や「演説」の場を提供しな がら,「人間交際」, そして「学問」の発展に寄与できるよ う努力していきたいと思います。 